\title{
Analisis Isi International Luxury Hotel di Bandung Berdasarkan TripAdvisor dan Agoda
}

\author{
Rachel Dyah Wiastuti, Naomi Hosana Wiliam \\ Bina Nusantara University, Jakarta \\ rwiastuti@binus.edu
}

\begin{abstract}
This study aims to determine the customer satisfaction factors and dissatisfaction factors for International Luxury Hotels in Bandung based on online reviews in TripAdvisor and Agoda platform. There are two hotels as research objects; Sheraton Bandung Hotel and Towers and InterContinental Bandung Dago Pakar. Content analysis techniques were conduct by analyzing 854 reviews representing consumer satisfaction and 30 reviews representing consumer dissatisfaction, obtained from two hotel platforms; TripAdvisor and Agoda. The results reveal 12 satisfaction factors; room quality, employee, food and beverages product, view and ambience, facilities, service quality, cleanliness, location, design, value, internet, parking area, and security. Meanwhile there are 12 dissatisfaction factors; operation issue, cleanliness, room quality, facilities, bathroom quality, service quality, employee, lack of quietness, accessibility and location, price, food and beverage products, and security.
\end{abstract}

Keywords - hotel attributes; luxury hotel; satisfaction factor; dissatisfaction factor

Abstrak-Tujuan penelitian ini adalah untuk mengidentifikasikan faktor yang menentukan kepuasan dan ketidakpuasan tamu pada International Luxury Hotel di Bandung berdasarkan ulasan daring yang ada di TripAdvisor dan Agoda. Objek penelitian terdiri dari dua hotel, yaitu Sheraton Bandung Hotel and Towers dan InterContinental Bandung Dago Pakar. Metode analisis isi dilakukan dengan cara melakukan analisis terhadap 854 ulasan yang mewakili kepuasan dan 30 ulasan yang mewakili ketidakpuasan yang didapatkan dari TripAdvisor dan Agoda. Hasil penelitian menunjukkan bahwa terdapat 12 faktor penentu kepuasan tamu, yaitu kualitas kamar, karyawan, suasana, fasilitas, kualitas pelayanan, kebersihan, lokasi, desain, nilai, internet, area parkir, dan keamanan. Terdapat juga 12 faktor penetu ketidakpuasan tamu yaitu isu operasional, kebersihan, kualitas kamar, fasilitas, kualitas kamar mandi, kualitas pelayanan, karyawan, kebisingan, aksesibilitas dan lokasi, harga, produk makanan minuman dan keamanan.

Kata kunci-atribut hotel; faktor kepuasan; faktor ketidakpuasan; hotel luxury

\section{PENDAhuluan}

Perkembangan teknologi mendukung berkembangnya keberadaan online travel agent yang berperan penting dalam sektor perhotelan pada industri pariwisata di Indonesia (Rinanda, 2016). Menurut Kotler, Bowen, \& Makens (2014), online travel agent adalah agen perjalanan wisata yang mengadakan bisnis melalui internet tanpa kantor dan lokasi secara fisik. Salah satu fitur yang menarik yang terdapat pada online travel agent yaitu adanya online review (Gretzel \& Yoo, 2008). Pelaku bisnis perhotelan dan online travel agent memanfaatkan media elektronik (Wiastuti \& Susilowardhani, 2015) dengan menyajikan online reviews sebuah hotel yang nantinya menjadi destinasi konsumen (Buhalis \& Licata dalam Putra \& Riorini 2016). Online review merupakan bagian dari Electronic Word of Mouth (eWOM), yaitu pendapat langsung dari seseorang dan bukan sebuah iklan (Farki, Baihaqi, \& Wibawa, 2016).
Online review sangat penting bagi perusahaan karena dapat menjadi media konsumen mencari kebutuhan informasi yang relevan akan suatu hotel (Putra \& Riorini, 2016). Selain itu online review pada media sosial dapat membantu peneliti untuk memahami kepuasan dan ketidakpuasan pelanggan (Berezina, Bilgihan, Cobanoglu, \& Okumus, 2015). Dalam perilaku konsumen, pemahaman terhadap kepuasan pelanggan akan menjadi kunci utama peningkatan kinerja layanan perusahaan (Anderson dalam Kim, Kim, \& Heo 2016). Sedangkan pemahaman terhadap ketidakpuasan pelanggan akan menjadi kunci untuk mengetahui penyebab kegagalan layanan atau buruknya perusahaan (Rhee \& Yang, 2015).

Bandung selain dikenal sebagai Ibukota Provinsi Jawa Barat dan Kota Kembang, juga terkenal akan tujuan wisata yang kaya akan wisata kuliner, budaya dan alam (Sitompul, Sutisna, \& Pharmawati, 2013). Trip Advisor merupakan salah satu platform hotel terbesar dan Agoda merupakan salah satu online travel 
agent yang berkembang sangat pesat, dimana keduanya dilengkapi fitur online reviews.

Tujuan dari penelitian ini adalah untuk mengetahui faktor apakah yang menentukan kepuasaan dan ketidakpuasan konsumen terhadap International Luxury Hotel di Bandung berdasarkan TripAdvisor dan Agoda. Terdapat tiga pertanyaan penelitian, yaitu (1) Bagaimana demografik konsumen yang puas dan tidak puas berdasarkan TripAdvisor dan Agoda? (2) Apa saja faktor yang menjadi penentu kepuasan konsumen pada International Luxury Hotel di Bandung berdasarkan TripAdvisor dan Agoda?, dan (3) Apa saja faktor yang menjadi penentu ketidakpuasan konsumen pada International Luxury Hotel di Bandung berdasarkan TripAdvisor dan Agoda?

\section{KAJIAN PUSTAKA}

\section{A. Atribut Hotel}

Atribut hotel merupakan bagian penting dari kriteria pemilihan hotel (Hananto, 2015). Pemahaman tentang hotel atribut dapat membantu manajer hotel untuk mengembangkan dan memposisikan hotel pada pasar persaingan bisnis dengan menyesuaikan atribut yang paling penting dan berpengaruh untuk konsumen (Xu \& Li, 2016).

Rhee \& Yang (2015) mengemukakan lima atribut hotel, yaitu value, location, sleep quality, rooms, cleanliness, dan service. Kim (2014) mengemukakan tujuh atribut, yaitu friendliness of staff, hotel amenities, hotel location, food quality, room cleanliness, room comfort, dan value for money. Hargreaves (2015) berpendapat hanya lima atribut, yaitu room, staff, view, service, dan location. Situs pemesanan online hotel juga menjabarkan hotel atribut berdasarkan kriterianya masingmasing. TripAdvisor (2018) membagi atribut hotel menjadi value, rooms, cleanliness dan service. Sedangkan Agoda (2018) membagi menjadi cleanliness, location, service, facilities, room comfort, room quality, dan value for money.

\section{B. Faktor Kepuasan Pada Hotel}

Kepuasan adalah perasaan senang atau kecewa seseorang yang muncul setelah membandingkan antara kinerja (hasil) produk yang dipikirkan terhadap kinerja (hasil) yang diharapkan (Thawil, 2014). Kepuasan konsumen dapat didefiniskan sebagai jumlah konsumen atau persentase dari total konsumen, yang telah melaporkan pengalamannya terhadap suatu firma, merasakan produk atau pelayanannya (ratings) yang melebihi suatu standar spesifik (Adesina \& Chinonso, 2015). Kepuasan konsumen merupakan kunci kesuksesan untuk bisnis di industri layanan konsumen (Adesina \& Chinonso, 2015).

Hargreaves (2015) mengemukakan lima faktor penentu kepuasan pada hotel, yaitu location, room quality, service quality, value, dan facilities. Darini \& Khozaei, (2016) juga mengemukakan lima faktor, yaitu location, food management, cleanliness, facilities, design dan employee. Kim, Kim \& Heo (2017) berpendapat hanya empat faktor, yaitu location, employee, room quality, food and beverage product. Khozaei, Nazem, Ramayah, \& Naidu (2016) menyatakan terdapat delapan faktor, yaitu room quality, facilities, internet, food and beverage product, value, location, cleanliness, dan employee. Sedangkan Limberger, Anjos, Meira \& Anjos (2014) menyatakan tiga faktor; room quality, service quality, dan value. Termasuk $\mathrm{Xu} \& \mathrm{Li},(2016)$ yang setuju akan tiga faktor penentu kepuasan; location, employee, dan room quality.

Maka didapatkan 10 faktor kepuasan yang telah diurutkan dari frekuensi kemunculan tertinggi hingga terkecil yang kemudian data ini yang digunakan untuk melakukan klasifikasi data pada analisis isi, yaitu employee, location, room quality, service quality, value, facilities, food and beverage, cleanliness, design, dan internet.

\section{Faktor Ketidakpuasan Pada Hotel}

Ketidakpuasan adalah keadaan dimana produk atau pelayanan yang diterima seseorang tidak sesuai atau berada di bawah standar yang diharapkan, hal ini menimbulkan kekecewaan terhadap penyedia produk atau pelayanan (Karakas, 2014). Kondisi dimana keadaan aktual yang berada di bawah ekspektasi yang diharapkan dapat menimbulkan ketidakpuasan (Darini \& Khozaei, 2016).

Hargreaves (2015) mengemukakan empat faktor penentu kepuasan pada hotel, yaitu employee, product functioning, pricing dan billing. Kim, Kim \& Heo (2017) berpendapat berbeda, bahwa terdapat tiga faktor ketidapuasan, yaitu employee, cleanliness, dan room quality. Begitu juga dengan $\mathrm{Xu} \& \mathrm{Li}$ (2016) yang menyatakan ada tiga faktor, yaitu facilities, employee, dan operations issue. Zheng, Youn \& Kincaid (2009) juga berpendapat tiga faktor, yaitu room quality, 
service quality dan value. Sedangkan Khozaei, Nazem, Ramayah, \& Naidu (2016) dan Asih \& Setiawan (2015) berpendapat sama bahwa terdapat dua faktor yaitu facilities and service quality.

Maka didapatkan 10 faktor ketidakpuasan yang telah diurutkan dari frekuensi kemunculan tertinggi hingga terkecil yang kemudian data ini yang digunakan untuk melakukan klasifikasi data pada analisis isi, yaitu employee, facilities, service quality, rooms quality, product functioning, pricing, billing, cleanliness, operational issue dan value.

\section{Luxury Hotel}

Luxury hotel memiliki dekorasi yang maksimal, serta memiliki layanan butler, concierge dan special concierge floors, secretarial services, Wi-Fi, komputer, mesin fax, salon kecantikan, spa, 24 jam room service, kolam renang, tennis courts, valet service, ticket office, kantor airline, penyewaan mobil, dan layanan kesehatan (Walker, 2014).

\section{Metode PENELITIAN}

Penelitian ini menggunakan pendekatan kualitatif deskriptif. Desain penelitian kualitatif adalah perencanaan penelitian yang sifatnya umum, garis besar, fleksibel, serta dimungkinkan berubah atau mengalami perkembangan dan penyempurnaan bersamaan dalam proses penelitian (Ibrahim, 2015). Sumber data primer didapat dari hasil analisis isi pada ulasan online konsumen pada objek penelitian berdasarkan online platform TripAdvisor dan Agoda.

TABEL 1. OBJEK PENELITIAN

\begin{tabular}{cll}
\hline No & \multicolumn{1}{c}{ Hotel } & \multicolumn{2}{c}{ Alamat \& Tlp } \\
\hline \multirow{3}{*}{1} & Sheraton Bandung & Jl. Ir. H.Djuanda \\
& No.390, Bandung, \\
& Hotel and Towers & Jawa Barat 40135 \\
& & T: +62 22 2500303 \\
& & J1. Resor Dago Pakar \\
& & Raya 2B, Resor \\
2 & InterContinental & Dago Pakar, \\
& Bandung Dago Pakar & Bandung \\
& & Jawa Barat 40198 \\
& & T: +62 22 87806688 \\
\hline
\end{tabular}

Sumber: Penulis (2018)

Populasi dalam penelitian ini adalah seluruh Luxury Hotel di Bandung yang berjumlah tiga hotel berdasarkan online platform TripAdvisor yang dikumpulkan pada tanggal 30 Maret 2018. Sampel dipilih secara non- probability sampling dan purposive sampling dengan pertimbangan pemilihan objek berdasarkan kategori International Hotel, sehingga didapatkan dua hotel yang menjadi sampel atau objek penelitian ini yang dapat dilihat pada Tabel 1 .

\section{A. Data Ulasan Online}

Berdasarkan Tabel 2 diketahui terdapat 1.068 ulasan konsumen pada TripAdvisor dan 748 ulasan konsumen pada Agoda. Berdasarkan Tabel 2 juga dapat diketahui bahwa sistem rating online pada TripAdvisor diklasifikasikan menjadi lima jenis yaitu excellent, very good, average, poor dan terrible. Sedangkan pada online platform Agoda sistem rating diklasifikasikan menjadi delapan jenis yaitu exceptional, excellent, very good, good, okay, average, poor, dan bad.

Rating adalah hasil penilaian yang dapat diandalkan untuk penelitian, karena konsumen dapat mengevaluasi keseluruhan selama menginap di hotel dan memberikan ulasan penilaian terhadap suatu hotel (Kim, Kim, \& Heo, 2016). Menurut Kim, Kim, \& Heo (2016) ulasan positif yang termasuk kedalam kategori "excellent" didefinisikan sebagai ulasan yang menunjukkan kepuasan dan ulasan negatif yang termasuk kedalam kategori "terrible" didefinisikan sebagai ulasan yang menunjukkan ketidakpuasan, sedangkan ulasan dalam kategori "good" dan kategori "poor" dikeluarkan.

TABEl 2. DATA UlasAn ONLINE

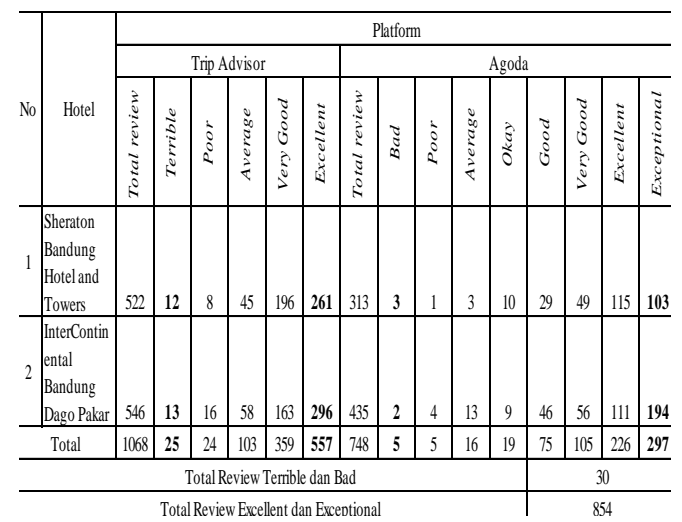

Sumber: Penulis (2018)

Penelitian ini hanya menggunakan ulasan dengan kategori terrible dan excellent pada situs TripAdvisor dan ulasan dengan kategori exceptional dan bad pada situs Agoda. Ulasan excellent dan exceptional digunakan sebagai ulasan yang mewakili kepuasan, sedangkan ulasan terrible dan bad digunakan sebagai ulasan yang mewakili ketidakpuasan. Tabel 2 menunjukkan total ulasan yang mewakili 
kepuasan konsumen dengan kategori excellent pada situs TripAdvisor berjumlah 557 ulasan dan ulasan dengan kategori exceptional pada situs Agoda berjumlah 297 ulasan. Sedangkan total ulasan yang mewakili ketidakpuasan dengan kategori terrible pada situs TripAdvisor berjumlah 25 ulasan dan review dengan kategori bad pada situs Agoda berjumlah 5 ulasan. Jumlah ulasan keseluruhan yang digunakan pada analisis isi sebanyak 854 ulasan yang mewakili kepuasan dan 30 ulasan yang mewakili ketidakpuasan, berdasarkan data yang diambil pada Mei 2018.

\section{B. Analisis Isi (Content Analysis)}

Penelitian ini menggunakan teknik content analysis dengan tujuan untuk mengetahui faktor yang menentukan kepuasan dan ketidakpuasan serta faktor yang paling menentukan kepuasan dan ketidakpuasan. Content analysis adalah satu pendekatan dan metode dalam penelitian kualitatif yang menjadikan teks sebagai objek kajian atau satuan yang dianalisis, dalam rangka menemukan makna atau isi pesan yang disampaikan (Ibrahim, 2015). Analisis isi digunakan untuk mempelajari dan menarik kesimpulan atas suatu fenomena, dengan memanfaatkan dokumen pada isi media cetak maupun elektronik (Almunaware, Regar, \& Senduk, 2015).

Terdapat lima langkah dalam analisis isi (Ibrahim, 2015) yang dilakukan dalam penelitian ini sesuai Gambar 1. Langkah pertama adalah menentukan teks yang akan diteliti, yaitu ulasan pada TripAdvisor dan Agoda. Langkah kedua adalah menentukan teks yang menarik, istimewa, luar biasa, kontroversial, yaitu ulasan yang hanya masul dalam kategori excellent, poor, rating satu, dan rating lima. Langkah ketiga adalah melakukan kategorisasi teks, yaitu menentukan faktor kepuasan dan faktor ketidakpuasan berdasarkan tinjauan pustaka penelitian terdahulu.

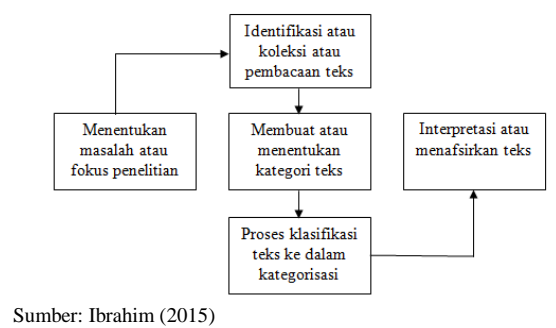

GAmbar 1. Alur KerJa ANALISIS IsI
Langkah keempat adalah melakukan klasifikasi ulasan dimana penulis menggunakan dua form sebagai alat bantu pencataan untuk mengelompokkan ulasan. Form pertama digunakan untuk klasifikasi ulasan dalam hal demographic reviewers' dan faktor kepuasan- ketidakpuasan, sedangkan form kedua digunakan untuk klasifikasi teks dalam hal atribut dari setiap faktor kepuasanketidakpuasan. Langkah kelima adalah memaknai, menafsirkan dan mengambil kesimpulan dari hasil klasifikasi ulasan.

\section{Hasil Penelitian dan PEMbahasan}

\section{A. Ulasan Daring Hotel}

Dalam penelitian ini, peneliti menganalisis ulasan tamu dari dua objek penelitian, yaitu Sheraton Bandung Hotel \& Towers dan Intercontinental Bandung Dago Pakar.

Tabel 3 menjabarkan hasil perhitungan faktor kepuasan dan ketidakpuasan ulasan tamu dalam bentuk nominal dan presentase serta penilaian keseluruhan yang kemudian dijadikan data dalam penelitian ini. Pada platform TripAdvisor, Sheraton Bandung Hotel and Towers memiliki total 603 ulasan yang terbagi menjadi 253 atau $42 \%$ ulasan kepuasan dan 12 atau $1,9 \%$ ulasan ketidakpuasan dan penilaian keseluruhan 4.5. Sedangkan pada platform Agoda Sheraton Bandung Hotel dan Towers memiliki total ulasan 482 yang terdiri dari 103 atau 22\% ulasan puas dan 3 atau 1,9\% ulasan tidak puas serta penilaian keseluruhan 8.1. Selain itu pada platform TripAdvisor InterContinental Bandung Dago Pakar memiliki total ulasan 585 dengan 295 atau 50,4\% ulasan puas dan 13 atau 2,2\% ulasan tidak puas dengan penilaian keseluruhan 4.5. Sedangkan pada platform Agoda InterContinental Bandung Dago Pakar memiliki total review 349 dengan 170 atau $48 \%$ ulasan puas dan 2 atau $0,5 \%$ ulasan tidak puas dengan penilaian keseluruhan 8.5. Jadi dapat dijumlahkan total ulasan kepuasan yang digunakan dalam penelitian ini sebanyak 854 ulasan, sedangkan ulasan ketidakpuasan sebanyak 30 ulasan. 
TABEL 3. UlASAN DARING HOTEL

\begin{tabular}{|c|c|c|c|c|c|}
\hline Hotel & $\begin{array}{c}\text { Platfor } \\
\mathrm{m}\end{array}$ & $\frac{\mathfrak{d}}{\sqrt[3]{\vdots}}$ & $\stackrel{5}{3}$ & 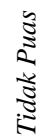 & 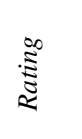 \\
\hline $\begin{array}{l}\text { Sheraton } \\
\text { Bandung }\end{array}$ & $\begin{array}{l}\text { TripAd } \\
\text { visor }\end{array}$ & 603 & 253 & 12 & $4.5 / 5$ \\
\hline $\begin{array}{l}\text { Hotel and } \\
\text { Towers }\end{array}$ & Agoda & 482 & 103 & 3 & $8.1 / 10$ \\
\hline $\begin{array}{l}\text { InterContine } \\
\text { ntal Bandung }\end{array}$ & $\begin{array}{l}\text { TripAd } \\
\text { visor }\end{array}$ & 585 & 295 & 13 & $4.5 / 5$ \\
\hline Dago Pakar & Agoda & 349 & 170 & 2 & $8.5 / 10$ \\
\hline
\end{tabular}

Sumber: Penulis (2018)

\section{B. TripAdvisor dan Agoda}

TripAdvisor didirikan pada tahun 2000 oleh Stefen Kaufer sebagai President dan CEO. TripAdvisor merupakan situs perjalanan wisata terbesar di dunia yang memungkinkan wisatawan untuk memanfaatkan potensi penuh dari setiap perjalanan (TripAdvisor, 2017). Dengan lebih dari 630 juta ulasan yang mencakup daftar perjalanan terbesar di seluruh dunia, sekitar 7,5 juta akomodasi, maskapai penerbangan, restoran dan pengalaman wisatawan (TripAdvisor, 2017). Adapun tagline yang digunakan oleh TripAdvisor yaitu "know better, book better and go better". (TripAdvisor, 2017). Pada tahun 2002 indeks popularitas TripAdvisor diluncurkan yang menentukan peringkat suatu properti berdasarkan ulasan konsumen yang membuat para pelaku bisnis di bidang perhotelan menyadari pentingnya ulasan postif dan dampak ulasan negatif terhadap nama baik hotel.

Agoda didirikan pada tahun 2005 dengan kantor pusat di Singapore, yang diakuisisi oleh Booking Holdings Inc pada 2007 yang merupakan perusahaan penjualan online tersbesar di dunia (Agoda, 2018). Booking Holdings Inc membawahi Agoda, Priceline.com, Kayak, Rentalcars.com, Booking.com dan OpenTable. Agoda memiliki 53 kantor yang tersebar di 30 negara dengan jumlah lebih dari 3.700 karyawan. Adapun tagline yang digunakan oleh Agoda yaitu "Book faster. Book smarter. Book Agoda" (Agoda, 2018). Gambar 2 menunjukkan logo TripAdvisor dan Agoda.

\section{बฮtripadvisor a g od a}

Sumber: TripAdvisor dan Agoda (2018)

GAMBAR 2. LOGO TRIPADVISOR DAN AGODA
C. Demographic Reviewers Kepuasan dan Ketidakpuasan

Gambar 3 menujukkan kunjungan reviewers yang memberikan ulasan kepuasan dan ketidakpuasan pada International Luxury Hotel di Bandung berdasarkan TripAdvisor dan Agoda.

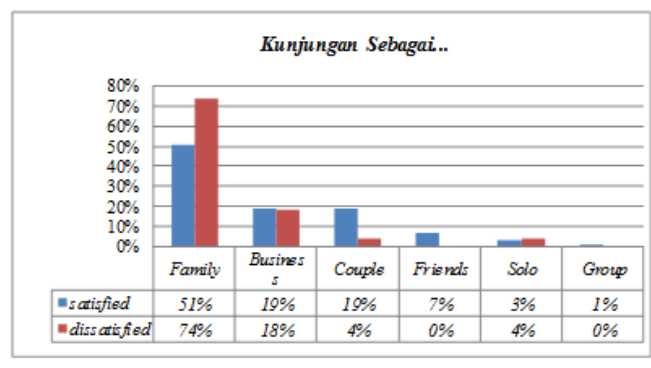

Sumber: Hasil Olah Data (2018)

\section{GAMBAR 3. KUNJUNGAN REVIEWERS}

Berdasarkan ulasan kepuasan, terdapat kunjungan bersama family sebanyak 51\%, kunjungan bersama rekan business sebanyak $19 \%$, wisatawan couple sebanyak $19 \%$, berkunjung bersama friends sebanyak 7\%, kunjungan solo sebanyak 3\%, kunjungan bersama group sebanyak 1\%. Sedangkan berdasarkan review tidak puas, terdapat kunjungan family sebanyak 74\%, business sebanyak $18 \%$, wisatawan couple sebanyak 4 $\%$, dan solo sebanyak 4\%. Sehingga dapat disimpulkan konsumen yang merasa puas maupun konsumen yang merasa tidak puas umumnya berasal dari wisatawan yang berkunjung bersama family.

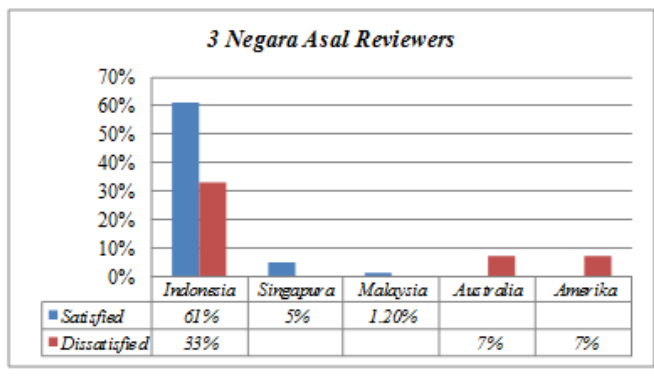

Sumber: Hasil Olah Data (2018)

GAMBAR 4. NEGARA ASAL REVIEWERS

Gambar 4 menujukkan asal negara reviewers yang memberikan ulasan kepuasan dan ketidakpuasan pada International Luxury Hotel di Bandung berdasarkan TripAdvisor dan Agoda. Terdapat tiga negara utama yang merupakan negara asal wisatawan yang memberikan ulasan puas dan tidak puas. Terdapat wisatawan yang paling banyak memberikan ulasan puas berasal dari Indonesia 
sebanyak $61 \%$ diikuti dengan negara Singapura sebanyak 5\% dan Malaysia $1.2 \%$. Berdasarkan ulasan tidak puas terdapat wisatawan asal Indonesia sebanyak 33\% diikuti dengan wisatawan Australia 7\% dan Amerika 7\%. Dapat disimpulkan bahwa wisatawan yang memberikan ulasan puas dan ulasan tidak puas mayoritas berasal dari negara Indonesia.

\section{Analisis Isi Faktor Kepuasan}

Berdasarkan hasil analisis isi dari 854 ulasan kepuasan, maka didapatkan 12 faktor yang menentukan kepuasan konsumen pada Tabel 4, yaitu room quality, employee, food and beverages product, view and ambience, facilities, service quality, cleanliness, location, design, value, internet, dan security.

Faktor room quality (18.05\%) menjadi faktor utama yang menentukan kepuasan konsumen, yang terdiri dari 5 atribut yaitu ukuran kamar yang luas, suasana yang nyaman di dalam kamar, kelengkapan amenities kamar (sampo, sabu, sikat gigi, pasta gigi, teh, dan kopi), ukuran kamar mandi yang luas, dan keindahan kamar mandi

Faktor employee (17.41\%) menempati urutan ke-2 sebagai faktor yang menentukan kepuasan konsumen, yang terdiri dari 8 atribut, yaitu keramahan staf, kontribusi staf dalam membantu tamu, tingkat profesionalitas staf, kesopanan staf, kemampuan staf dalam berbahasa Inggirs, pengetahuan staf baik tentang produk hotel maupun daerah sekitar misalnya wisata terdekat, makanan tradisional. Selain itu aspek lainnya seperti cara staf memperhatikan tamu, kinerja staf yang baik termasuk kecepatan dalam bekerja.

TABEL 4. FAKTOR KEPUASAN

\begin{tabular}{lccc}
\hline $\begin{array}{l}\text { Faktor } \\
\text { Kepuasan }\end{array}$ & Rank & $\begin{array}{c}\text { Jumlah } \\
\text { Ulasan }\end{array}$ & $\%$ \\
\hline Room quality & 1 & 417 & $18.05 \%$ \\
$\begin{array}{l}\text { Employee } \\
\text { Food and }\end{array}$ & 2 & 402 & $17.41 \%$ \\
beverages & 3 & 329 & $14.24 \%$ \\
View and & 4 & 302 & $13.07 \%$ \\
ambience & & & \\
Facilities & 5 & 254 & $11 \%$ \\
Service quality & 6 & 188 & $8.14 \%$ \\
Cleanliness & 7 & 158 & $6.84 \%$ \\
Location & 8 & 152 & $6.58 \%$ \\
Design & 9 & 67 & $2.9 \%$ \\
Value & 10 & 23 & $0.99 \%$ \\
Internet & 11 & 14 & $0.60 \%$ \\
Security & 12 & 3 & $0.12 \%$ \\
\hline
\end{tabular}

Sumber: Hasil Olah Data (2018)

Faktor food and beverages product (14.24\%) menempati urutan ke-3 sebagai faktor yang menentukan kepuasan konsumen, yang terdiri dari 4 atribut, yaitu rasa makanan yang enak, variasi makanan yang banyak, kualitas makanan yang baik seperti tampilan, dan adanya menu vegetarian.

Faktor view dan ambience (13.07\%) menempati urutan ke-4 sebagai faktor yang menentukan kepuasan konsumen, yang terdiri dari 2 atribut, yaitu pemandangan yang bagus yang dapat dinikmati tamu baik dari dalam kamar maupun dari area lainnya, seperti area lobi, restoran, kolam renang, dan taman. Selain itu suasana hotel tenang dan nyaman seperti lingkungan hotel, ketenangan sekitar hotel.

Faktor facilities (11\%) menempati urutan ke-5 sebagai faktor yang menentukan kepuasan konsumen, yang terdiri dari 9 atribut, yaitu kolam renang (konsep infinity pool, kolam renang dengan air hangat), fasilitas hotel yang lengkap, fasilitas hotel yang bagus, fasilitas gym (alat gym modern dan banyak pilihan), spa yang menyenangkan, terdapat kelas renang di hotel, fasilitas untuk anak-anak (naik kuda, menggambar, ruang khusus video games), arena untuk bermain golf, meeting room, tingkat kenyamanan di restoran, serta parking area. Dalam hal ini tamu merasa nyaman karena hotel memiliki tempat parkir yang luas, sehingga tamu tidak kesulitan untuk mencari tempat parkir, karena ketersediaan lahan parkir yang besar.

Faktor service quality $(8.14 \%)$ menempati urutan ke-6 sebagai faktor yang menentukan kepuasan konsumen, yang terdiri dari 15 atribut, yaitu fasilitas airport transfer dimana tamu mendapatkan antar-jemput menuju atau dari bandara secara gratis, mendapatkan welcome drink atau welcome snack berupa jus atau kue ketika tamu sampai di hotel, prosedur dan proses check-in yang mudah dan baik, mendapatkan kejutan ulang tahun maupun wedding anniversarry dari hotel, kamar upgrade tanpa tambahan biaya, mendapatkan komplimen buah, mendapatkan pelayanan yang baik dari hotel, disediakan kendaraan untuk tamu hotel misalnya tamu-tamu yang kehujanan dan ingin ke restoran namun harus terkena hujan maka hotel menyediakan kendaraan agar tamu tersebut bisa ke restoran tanpa terkena hujan, pelayanan yang cepat, tamu yang sakit diberikan obat, tamu diajak berkeliling melihat fasilitas hotel, serta peminjaman baby crib untuk tamu yang membawa bayi, tamu juga mendapatkan hadiah dari hotel, dipinjamkan charger, dan 
termasuk barang milik tamu yang hilang masih disimpan oleh pihak hotel.

Faktor cleanliness menempati urutan ke-7 sebagai faktor yang menentukan kepuasan konsumen, yang terdiri dari 2 atribut, yaitu kebersihan kamar seperti karpet yang bersih, sudut kamar tanpa debu, bed sheet yang bersih tanpa noda dan kebersihan area hotel seperti lobi, toilet, dan lift.

Faktor location $(6.58 \%)$ menempati urutan ke-8 sebagai faktor yang menentukan kepuasan konsumen, yang terdiri dari 3 atribut, yaitu lokasi yang baik atau strategis dimana lokasi mudah diakses, mudah ditemui, lokasi yang terletak dekat dengan tempat wisata, sehingga memudahkan konsumen untuk mencari hiburan di sekitar hotel. Selain itu lokasi dapat disebut sebagai tempat yang cocok untuk berlibur, dimana lokasi tersebut tenang, jauh dari keramaian, sehingga tamu dapat menikmati suasana liburan yang baik dan nyaman.

Faktor design (2.9\%) menempati urutan ke9 sebagai faktor yang menentukan kepuasan konsumen, yang terdiri dari 5 atribut, yaitu desain menarik dan unik seperti pada lukisan, langit-langit dan lantai. Selain itu terdapat aspek desain mewah, moderen, dan memiliki kualitas furniture yang bagus baik furniture di dalam kamar, di lobi, restoran, maupun di area lainnya. Selain itu interior hotel yang bagus juga menjadi aspek, dalam hal ini interior yang bagus termasuk interior kamar, lobi, ballroom, dan restoran.

Faktor value $(0.99 \%)$ menempati urutan ke-10 sebagai faktor yang menentukan kepuasan konsumen, yaitu harga yang sesuai dengan apa yang konsumen dapatkan. Tamu tidak merasa dirugikan karena biaya yang dikeluarkan oleh tamu sepadan dengan apa yang diterima misalnya tamu merasa harga cocok dengan pelayanan.

Faktor internet $(0.6 \%)$ menempati urutan ke-11 sebagai faktor yang menentukan kepuasan konsumen, yang terdiri dari atribut, yaitu kecepatan koneksi internet dimana tamu tidak perlu menunggu lama untuk mengakses konten dalam internet. Selain itu fasilitas wi-fi gratis di dalam kamar membuat tamu tidak perlu turun dari area kamar dan menunggu di lobby hanya untuk menggunakan wi-fi, sehingga tamu merasa nyaman dan efisien.

Faktor security $(0.2 \%)$ menempati urutan ke-12 atau paling kecil sebagai faktor yang menentukan kepuasan konsumen, yaitu keamanan yang dirasakan tamu baik dalam hal barang-barang yang ditinggalkan tamu di dalam kamar dan area hotel, ataupun keamanan lingkungan hotel.

\section{E. Analisis Isi Faktor Ketidakpuasan}

Berdasarkan hasil analisis isi dari 30 ulasan ketidakpuasan, maka didapatkan 12 faktor yang menentukan kepuasan konsumen pada Tabel 5, yaitu operation issue, cleanliness, room quality, facilities, bathroom quality, service quality, employee, lack of quietness, accesibility and location, pricing, food and beverages product, dan security.

\section{TABEL 5. FAKTOR KETIDAKPUASAN}

\begin{tabular}{lccc}
\hline Faktor & $\begin{array}{c}\text { Ran } \\
\text { Ketidakpuasan }\end{array}$ & $\begin{array}{c}\text { Jumlah } \\
\text { Ulasan }\end{array}$ & $\%$ \\
\hline Operation issue & 1 & 11 & $16.92 \%$ \\
Cleanliness & 2 & 8 & $12.3 \%$ \\
Room quality & 3 & 8 & $12.3 \%$ \\
Facilities & 4 & 7 & $10.76 \%$ \\
Bathroom quality & 5 & 7 & $10.76 \%$ \\
Service quality & 6 & 6 & $9.23 \%$ \\
Employee & 7 & 5 & $7.69 \%$ \\
Lack of quietness & 8 & 4 & $6.15 \%$ \\
Accesibility and & 9 & 3 & $4.61 \%$ \\
location & & & \\
Pricing & 10 & 2 & $3.07 \%$ \\
Food and beverages & 11 & 2 & $3.07 \%$ \\
product & & & \\
Security & 12 & 2 & $3.07 \%$ \\
\hline
\end{tabular}

Sumber: Hasil Olah Data (2018)

Faktor operation issue (16.92\%) menjadi faktor utama yang menentukan ketidakpuasan konsumen, yang terdiri dari 3 atribut yaitu check-in proses yang lama dan tidak efisien, kamar yang didapat tidak sesuai dengan pemesanan, dan tidak ada kamar yang tersedia ketika tamu datang. Faktor cleanliness $(12.3 \%)$ menempati urutan ke-2 sebagai faktor yang menentukan ketidakpuasan konsumen, yang terdiri dari 4 atribut yaitu kamar hotel yang kotor dan bau rokok, terdapat lalat pada area lobi hotel, gelas yang disediakan di dalam kamar dalam keadaan kotor, dan kondisi kolam renang yang kotor.

Faktor room quality (12.0\%) menempati urutan ke-3 sebagai faktor yang menentukan ketidakp `uasan konsumen, yang terdiri dari 5 atribut yaitu amenities yang tidak lengkap, AC rusak, fasilitas dalam kamar tidak baik, kualitas kamar yang buruk, serta kulkas di dalam kamar yang tidak berfungsi dengan baik. Faktor facilities (10.76\%) menempati urutan ke-4 sebagai faktor yang menentukan ketidakpuasan konsumen, yang terdiri dari 5 atribut yaitu telepon kamar yang rusak atau tidak berfungsi, kolam renang yang kecil, tidak 
adanya lift, koneksi internet yang buruk atau lama, dan ukuran restoran yang kecil.

Faktor bathroom quality (10.76\%) menempati urutan ke-5 sebagai faktor yang menentukan ketidakpuasan konsumen, yang terdiri atribut yaitu toilet pada kondisi bau, banjir, shower mengeluarkan pancuran air yang sedikit, tidak terdapat ada bathtub, handuk yang robek, toilet bowl rusak.

Faktor service quality (9.23\%) menempati urutan ke-6 sebagai faktor yang menentukan ketidakpuasan konsumen, yang terdiri dari 3 atribut yaitu pelayanan yang lama dan buruk misalnya dalam pelayanan room service, pesanan yang lambat dan tidak efisien. Selain itu pelayanan yang dirasa tamu mengganggu seperti permintaan maaf pada jam tidur.

Faktor employee (7.69\%) menempati urutan ke-7 sebagai faktor yang menentukan ketidakpuasan konsumen, yang terdiri dari 3 atribut yaitu konsumen tidak disambut oleh karyawan hotel, kurangnya pemahaman mengenai produk dan informasi yang dimiliki oleh karyawan hotel, serta karyawan yang tidak profesional dalam bekerja.

Faktor lack of quietness (6.15\%) menempati urutan ke-8 sebagai faktor yang menentukan ketidakpuasan konsumen, yang terdiri dari 2 atribut yaitu suasana yang berisik di sekitar hotel dan kamar, dan kamar yang tidak kedap suara sehingga terdengar pembicaraan dari kamar sebelah dan banyak anak-anak yang berlari di koridor, merupakan salah satu alasan tamu menjadi tidak puas.

Faktor accesibility and location (4.61\%) menempati urutan ke-9 sebagai faktor yang menentukan ketidakpuasan konsumen, yang terdiri dari 2 atribut yaitu lokasi yang buruk karena sulit dijangkau jika tidak terdapat transportasi serta terletak di pusat kemacetan. Akses menuju basement buruk karena kotor gelap dan hanya difasilitasi tangga, serta letak kamar yang jauh dari area lobi sehingga tamu harus berjalan cukup jauh menuju kamar.

Faktor pricing $(3.07 \%)$ menempati urutan ke-10 sebagai faktor yang menentukan ketidakpuasan konsumen, yang terdiri dari 2 atribut yaitu tamu merasa harga yang dibayarkan mahal karena tidak sesuai dengan kualitas, serta adanya perubahan harga yang tiba-tiba seperti harga yang tidak cocok pada saat pemesanan dengan waktu pembayaran saat di hotel.
Faktor food and beverages product (3.07\%) menempati urutan ke-11 sebagai faktor yang menentukan ketidakpuasan konsumen, yang terdiri dari 2 atribut yaitu kualitas makanan yang buruk dengan rasa yang tidak enak dan penyajian yang tidak baik seperti makanan yang sudah dingin. Selain itu pilihan makanan yang sedikit juga menjadi alasan sehingga tamu merasa monoton dengan makanan yang disajikan, serta sulit bagi wisatawan asing untuk menemukan makanan yang cocok dengan seleranya. Faktor security (3.07\%) menempati urutan ke-12 atau paling kecil sebagai faktor yang menentukan ketidakpuasan konsumen, yaitu pintu kamar yang terbuka saat housekeeping selesai membersihkan kamar, sehingga tamu merasa keamanan kurang diperhatikan karena kelalaian housekeeping yang tidak menutup pintu. Selain itu terdapat hewan di dalam kamar membuat tamu merasa kurangnya keamanan karena hewan bisa masuk kedalam kamar.

\section{KESIMPULAN}

Berdasarkan hasil analisis isi, terdapat 12 faktor yang menentukan kepuasan konsumen dari total ulasan konsumen yang merasa puas terhadap International Luxury Hotel di Bandung berdasarkan TripAdvisor dan Agoda yang berjumlah 854 ulasan, yaitu ${ }^{1}$ room quality, ${ }^{2}$ employee, ${ }^{3}$ food and beverages product, ${ }^{4}$ view and ambience, ${ }^{5}$ facilities, ${ }^{6}$ service quality, ${ }^{7}$ cleanliness, ${ }^{8}$ location, ${ }^{9}$ design, ${ }^{10}$ value, ${ }^{11}$ internet, dan ${ }^{12}$ security. Terdapat 12 faktor yang menentukan ketidakpuasan konsumen terhadap International Luxury Hotel di Bandung berdasarkan platform TripAdvisor dan Agoda yang berjumlah 30 ulasan yaitu ${ }^{1}$ operation issue, ${ }^{2}$ cleanliness, ${ }^{3}$ room quality, ${ }^{4}$ facilities, ${ }^{5}$ bathroom quality, ${ }^{6}$ service quality, ${ }^{7}$ employee ${ }^{8}$ lack of quietness, ${ }^{9}$ accesibility and location, ${ }^{10}$ pricing, ${ }^{11}$ food and beverages dan ${ }^{12}$ security.

Faktor utama yang menentukan kepuasan konsumen pada situs TripAdvisor dan Agoda adalah faktor room quality sebesar $18.05 \%$ yang meliputi aspek ukuran kamar yang luas, kamar yang nyaman, ukuran kamar mandi yang luas, dan amenities kamar yang tersedia (sabun, sampo, sikat gigi, pasta gigi, teh, kopi). Sedangkan faktor utama yang menentukan ketidakpuasan konsumen adalah faktor operation issue sebesar $16.92 \%$ yang meliputi proses check-in dan check-out yang membutuhkan waktu lama, kamar yang tidak sesuai dengan pesanan, serta tidak tersedia kamar yang dipesan saat check-in. 
Rekomendasi yang disarankan untuk pihak pengelola hotel adalah (1) Meningkatkan kecepatan dalam layanan check-in check-out, (2) Meningkatkan kebersihan di dalam kamar, khususnya pada karpet, sudut kamar dan jendela, (3) Meningkatkan kualitas kamar mandi di dalam kamar, khususnya bagian toilet bowl agar berfungsi dengan baik, (4) Meningkatkan kecepatan koneksi internet yang lambat, dan (5) Membuat kualitas kamar yang kurang kedap suara menjadi lebih kedap suara.

Rekomendasi untuk penelitian selanjutnya yaitu penambahan objek penelitian dengan melibatkan National Luxury Hotel di Bandung. Objek penelitian juga dapat dilakukan pada Luxury Hotel di kota lainnya seperti Jakarta dan Bali. Selain itu, ulasan yang dianalisis dapat berasal dari situs yang berbeda seperti Traveloka, Expedia, dan Booking.com.

\section{DAFTAR RUJUKAN}

Adesina, K. I., \& Chinonso, I. (2015). Service Delivery and Customer Satisfication In Hospitality Industry: A study of the Devine Fountain Hotel Limited, Lagos, Nigeria. Journal of Hospitality and Management, 6(1), 1-7.

Agoda (2018). Agoda.

Berezina, K., Bilgihan, A., Cobanoglu, C., \& Okumus, F. (2015). Understanding Satisfied and Dissatisfied Hotel Customers: Text Mining of Online Hotel. Journal of Hospitality Marketing \& Management. 25 (1). 1-24

Darini, M., \& Khozaei, F. (2016). The Study of Factors Affecting Customer's Satisfaction with The Three Star Hotels in Dubai. International Journal of Advanced Engineering, Management and Science, 2(2), 21-24.

Farki, A., Baihaqi, I., \& Wibawa, B. M. (2016). Pengaruh Online Customer Review dan Rating Terhadap Kepercayaan dan Minat Pembelian pada Online Marketplace di Indonesia. Jurnal teknik ITS, 5(2).

Gretzel, U. and Yoo, K.H. (2008). Use and Impact of Online Travel Reviews. Information and Communication Technologies in Tourism 2008. Proceedings of the International Conference in Innsbruck, Austria Springer-Verlag Wien, 35-46.

Hananto, A. (2015). Application of Text Mining to Extract Hotel Attributes and Construct Perceptual Map of Five Star Hotels from Online Review: Study of
Jakarta and Singapore Five-Star Hotels. Asean Marketing Journal, 7(2), 58-80.

Hargreaves, C. A. (2015). Analysis of Hotel Guest Satisfaction Ratings and Reviews: An Application in Singapore. American Journal of Marketing Research, 208-214.

Ibrahim. (2015). Metodologi Penelitian Kualitatif Panduan Penelitian beserta Contoh Proposal Kualitatif. $1^{\text {st }}$ ed. Perpustakaan Nasional.

Karakas, M. K. (2014). Importance and Impact of Guest Satisfaction. Applied Studies in Agribusiness and Commerce, 8(4), 31-37

Khozaei, F., Nazem, G., Ramayah, T., \& Naidu, S. (2016). Factors Predicting Travelers' Satisfaction of Three to Five Star Hotels in Asia, an Online Review. International Journal of Research in Tourism and Hospitality, 2(2), 30-41.

Kim, M. R. (2014). The Relationship Between Leisure Traveler Hotel Attribute Satisfaction and Overall Satisfaction. Hospitality Review 31(1).

Kim, B., Kim, S., \& Heo, C. Y. (2016). Analysis of Satisfiers and Dissatisfiers In Online Hotel Reviews on Social Media. International Journal of Contemporary Hospitality Management, 28(9).

Kotler, P., Bowen, J. T., \& Makens, J. C. (2014). Marketing for Hospitality adn Tourism ( $6^{\text {th }}$ ed). New Jersey: Pearson

Limberger, Anjos, Meira, \& Anjos (2014). Satisfaction in Hospitality on TripAdvisor.com: An Analysis of the Correlation Between Evaluation Criteria and Overall Satisfaction. Tourism \& Management Studies Journal, 10(1), 6065

Putra, S. A., \& Riorini, S. V. (2016). Pengaruh Online Reviews Terhadap Online Hotel Booking Intetntions Pada Online Travel Agent Lokal. Seminar Nasional Cendikiawan

Rhee, H. T., \& Yang, S. B. (2015). Does Hotel Attribute Importance Differ by Hotel? Focusing on Hotelstar-Classifications and Customers' Overall Ratings. Computer in Human Behavior, 50, 576- 587.

Rinanda, S. I. (2016). Faktor Yang Mempengaruhi Loyalitas Karyawan Di Hotel Dyan. JOM FISIP, 3(2).

Sitompul, D. F., Sutisna, M., \& Pharmawati, K. (2013). Pengolahan Limbah Cair Hotel Aston Braga City Walk Dengan Proses Fitoremediasi Menggunakan Tumbuhan Eceng Gondok. Jurnal Institut Teknologi Nasional, 2(1). 
Thawil, A. N. (2014). Pengaruh Ketidakpuasan Pasca Konsumsi Dan Kebutuhan Mencari Variasi Terhadap Keputusan Perpindahan Merek Handphone GSM Dari Merk Blackberry ke Samsung. Jurnal Riset Bisnis dan Manajemen, 2(4).

TripAdvisor (2018). TripAdvisor. (TripAdvisor LLC)

Walker, J. R. (2014). Introducing Hospitality. 6th ed.). London: Pearson

Wiastuti, R.D. \& Susilowardhani, E.M. (2015). Element ofMarketing Communication Mix for Hotel with Sharia Concept (Study Case in Sofyan Hotel Betawi). Proceeding of ICCOMAC 2015. Jakarta

$\mathrm{Xu}, \mathrm{X}$., \& Li, Y. (2016). The Antecedents of Customer Satisfaction And Dissatisfaction Toward Various Type Of Hotel: A Text Mining Approach. International Journal of Hospitality Management, 55.

Zheng, T., Youn, H., \& Kincaid, C.S. (2009). An Analysis of Customers' E-Complaints for Luxury Resort Properties. Journal of Hospitality Marketing \& Management, 18 (7), 718-729. 